\title{
Functional capacity and social support to people affected by cerebrovascular accident
}

\author{
Capacidade funcional e apoio social de pessoas acometidas por acidente vascular encefálico \\ Capacidad funcional y apoyo social de personas afectadas por accidente cerebrovascular
}

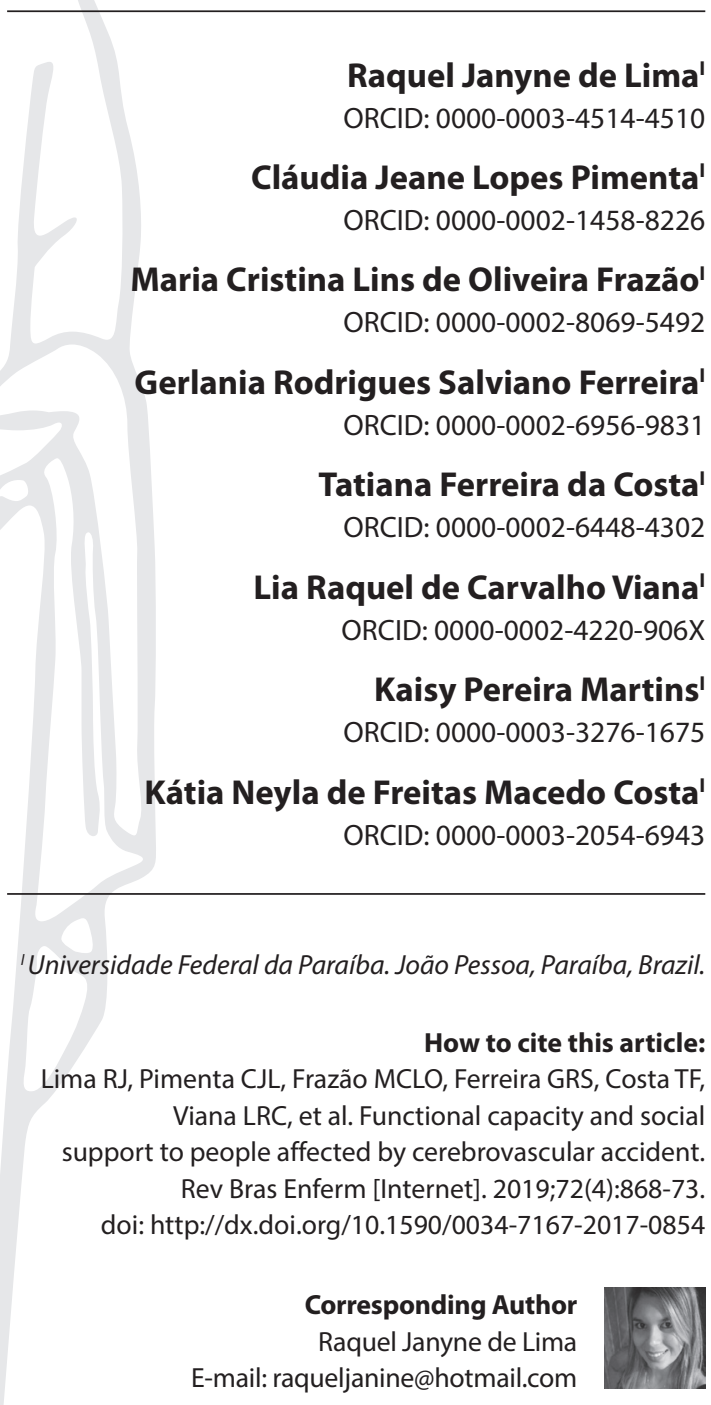

Submission: 11-12-2017

Approval: 10-15-2018

\section{ABSTRACT}

Objective: To investigate the functional capacity and its relationship with the level of social support to people affected by cerebrovascular accident. Methods: Crosssectional and quantitative research, conducted with 108 individuals with sequelae of cerebrovascular accident in João Pessoa/PB. Data were collected through interviews, using a sociodemographic instrument - the Barthel Index and the Social Support Scale. Results: We observed the prevalence of functional dependency in $93.5 \%$, and the mild dependency stood out in $40.7 \%$. Medium social support was the most found, with $48.2 \%$. The predominant dimensions of social support were the material dimension, followed by the emotional. There was a significant association $(p \leq 0.05)$ between very serious dependency and high social support. Conclusion: The results found allow us to reflect on the need for involvement of health professionals in strengthening the social support of patients with disabling diseases, such as the cerebrovascular accident. Descriptors: Stroke; Activities of Daily Living; Social Support; Family Health Strategy; Nursing.

\section{RESUMO}

Objetivo: Investigar a capacidade funcional e a sua relação com o nível de apoio social de pessoas acometidas por acidente vascular encefálico. Métodos: Pesquisa transversal e quantitativa, realizada com 108 indivíduos com sequelas de acidente vascular encefálico em João Pessoa/PB. Os dados foram coletados por entrevistas, utilizando um instrumento sociodemográfico, o Índice de Barthel e a Escala de Apoio Social. Resultados: Foi observada uma prevalência de dependência funcional de $93,5 \%$ e destacou-se a dependência leve em $40,7 \%$. O apoio social médio foi o mais encontrado, com 48,2\%. As dimensões da escala de apoio social que predominaram foram a dimensão material seguida da emocional. Evidenciou-se uma associação significativa $(p \leq 0,05)$ entre dependência muito grave e apoio social alto. Conclusão: Os resultados encontrados permitem refletir sobre a necessidade do envolvimento dos profissionais de saúde no fortalecimento do apoio social aos pacientes acometidos por doenças incapacitantes, como o acidente vascular encefálico. Descritores: Acidente Vascular Cerebral; Atividades Cotidianas; Apoio Social; Estratégia Saúde da Família; Enfermagem.

\section{RESUMEN}

Objetivo: Investigar la capacidad funcional y su relación con el nivel de apoyo social de personas afectadas por accidente cerebrovascular. Métodos: Investigación transversal y cuantitativa realizada en João Pessoa (PB, Brasil), en el cual participaron 108 individuos con secuelas de accidente cerebrovascular. La recopilación de datos se realizó mediante entrevistas, utilizando como instrumento sociodemográfico el Índice de Barthel y la Escala de apoyo social. Resultados: Se observó una prevalencia de dependencia funcional en un $93,5 \%$, y se destacó una menor dependencia en un $40,7 \%$. El apoyo social medio fue lo más encontrado, con un $48,2 \%$. Las dimensiones de la Escala de apoyo social más predominantes fueron la dimensión material, seguida de la emocional. Se observó una asociación significativa $(p \leq 0,05)$ entre la dependencia muy grave y el alto apoyo social. Conclusión: Los resultados encontrados apuntan la necesidad de la participación de los profesionales de la salud en el fortalecimiento del apoyo social a los pacientes afectados por enfermedades debilitantes, como el accidente cerebrovascular.

Descriptores: Accidente Cerebrovascular; Actividades Cotidianas; Apoyo Social; Estrategia de Salud Familiar; Enfermería. 


\section{INTRODUCTION}

Cerebrovascular accident (CVA) is a syndrome which consists of the rapid development of focal clinical disorders of cerebral function, lasting more than 24 hours. Featuring a high morbidity, this is the main reason of disability and use of health resources in the United States ${ }^{(1)}$. In Europe, especially in Portugal, it remains the most significant cause of morbidity of potential lost of years of life ${ }^{(2)}$. At a national level, more then 289,000 cases of hospitalizations were identified between 2013 and 2017 (3).

The CVA became the second leading cause of death in the world, and Brazil is the country with the highest mortality rates in Latin American, leading to approximately 125,000 deaths among patients hospitalized due to CVA in the last five years, which corresponds to a rate of 15.17 for every thousand inhabitants ${ }^{(3-4)}$. As it is regarded as the major cause of long-term disablement, this pathology results in varying degrees of chronic disability ${ }^{(5)}$.

Functional incapacity refers to the difficulty or need of help for the individual to perform daily tasks, covering two types: Basic Activities of Daily Living (BADL) and Instrumental Activities of Daily Living $(I A D L)^{(6)}$. The BADL are related to self-care, whereas IADL are relates to participation in the social environment ${ }^{(7)}$.

People affected by CVA often return home with physical and cognitive-behavioral sequelae, which usually compromise the functional capacity, often making them dependent on other people. This situation has been considered a stressing event for the family, causing changes involving affective and financial aspects ${ }^{(8)}$. In addition, the weaknesses and lack of structure of the health system are a major problem in the comprehensiveness and continuity of care after the patient's hospital discharge ${ }^{(9)}$.

The support network is essential in rehab and in increasing the independence and social rehabilitation of the patient, as it is an important tool in the patient's coping and adaptation to this new reality, which results in positive behaviors. Commonly, the family is the major source of social support, as well as neighbors and friends, in addition to health professionals who are involved in the process ${ }^{(10)}$.

Among the constructs involving social ties, the concepts of social support and network are highlighted. Social network can be defined as the group of people with whom the individual has contact or some form of social link, which may or may not offer help in various situations throughout life. Social support, in turn, is related to resources of the network made available by other people in situations of need ${ }^{(11)}$.

Social support is a multidimensional construct that has been related to several outcomes in health and is considered an important factor in the adaptation process to adverse life situations, such as stress and illnesses. However, depending on the nature of the support from their social contacts, it may influence positively or negatively on health-related behaviors ${ }^{(12)}$.

Traditionally, social support has been divided into five dimensions: material, reflecting the individuals' access to practical services and material resources; affective, involving expressions of love and affection; emotional, referring to empathy, trust, esteem, affection, listening and interest; positive social interaction, which concerns the availability of people with whom to have fun and relax; and information, dealing with guidance and counseling ${ }^{(13)}$.

Although the social support has a major role in the promotion of health and prevention of diseases and disabilities, studies addressing its relationship with individual levels of functional capacity are still incipient, particularly among patients presenting after effects of CVA; there is a larger number of investigations concerning the older population ${ }^{(14)}$. A study conducted with 39 older adults in a Family Health Strategy of Uberaba/MG showed a statistically significant correlation between social support and functionality, in that the higher the perception of the older people regarding their support network, the better was their functional capacity ${ }^{(15)}$.

Thus, this study becomes relevant, as we sought to investigate the presence of factors related to social support and their influence on the functional capacity of patients with sequelae of CVA. Considering the aspects here addressed, the inquiring of this study was: what is the level of social support, and what its relationship with functional capacity, in patients presenting sequelae of CVA?

\section{OBJECTIVE}

To investigate the functional capacity and its relationship with the level of social support to people affected by CVA.

\section{METHODS}

\section{Ethical aspects}

The research was developed in accordance with Resolution $466 / 2012$ of the National Health Council. There was approval from the Research Ethics Committee of the Health Sciences Center of the Federal University of Paraíba. Participants were informed of its goals, as well of its possible risks, benefits and confidentiality, and signed the Informed Consent Form.

\section{Study design, location and period}

This is a cross-sectional, quantitative study, performed in the Family Health Units (FHU) in the municipality of João Pessoa, Paraíba, Brazil, from April to October 2016.

\section{Study sample; inclusion and exclusion criteria}

The study population consisted of patients affected by CVA and who were registered in the FHU of the municipality. The sample was calculated from the total number of hospitalizations in the six months prior to collection, in the SUS hospital network of the municipality ${ }^{(3)}$, with confidence interval at $95 \%(a=0.05$, providing $Z 0.05 / 2=1.96)$, estimated prevalence of $50 \%(p=0.50)$ for the presence of after effects and $5 \%$ margin of error $(\text { Error }=0.05)^{(3)}$, totaling 108 individuals.

Inclusion criteria were: 18 years old or older, residing in João Pessoa/ $\mathrm{PB}$, receiving care from a FHU and having at least one kind of after affect from the CVA, as reported by the own patient or the caregiver. Exclusion criteria were: presenting some dementia, cognitive delay or mental illness already diagnosed and, as sequelae of CVA, changes in communication, hearing or memory, reported by a family member or caregiver, as these conditions could compromise data collection.

\section{Study protocol}

The study was conducted in $51 \mathrm{FHUs}$, selected at random through a simple draw. Data were collected by the researchers through 
individual semi-structured interviews, held at the residence of patients with CVA sequelae, having an average length of 30 minutes.

Functional capacity was measured using the Barthel Index, which aims to identify the level of care required by a person who presents some kind of disability. It evaluates ten items concerning: bowel and bladder sphincters control, ability to perform personal hygiene, feeding, using the bathroom, moving from chair to bed, walking, dressing, climb stairs and bathing. Scores range from 0 to 20, as follow: 0 to 4 (very seriously dependent), 5 to 9 (seriously dependent), 10 to 14 (moderately dependent), 15 to 19 (slightly dependent), and 20 (independent) ${ }^{(16)}$. It presented a Cronbach's alpha of 0.879 foe all items.

The Social Support Scale elaborated by Sherbourne and Stewart, of the Medical Outcomes Study, was also used, being adapted and validated $^{(17)}$ for the Brazilian reality. This was chosen due to its good levels of reliability and ease in understanding and application. According to a literature review, $45 \%$ of the Brazilian studies that discuss the subject used this scale for measuring social support; hence, this is the most popular instrument in the country ${ }^{(18)}$. It consists of five dimensions, with 19 questions: material, affective, emotional, information support and positive social interaction. Answers range from 1 (never) to 5 (always), and the final score varies from 19 to 95 points ${ }^{(17)}$, in which the higher the score, the higher is the social support.

As the scale does not submit a specific classification for social support, this study used the minimum and maximum scores shown by the participants ( 39 and 95 points, respectively), distributed in form of quartiles. In this type of calculation, values are divided into four equal parts of 25\%, in which the quartile 1 (Q1) corresponds to the $25 \%$ lowest values, quartile 2 (Q2) delimits the $50 \%$ values, and quartile 3 (Q3) covers the $25 \%$ greatest values. Thus, scores up to 67 correspond to low social support; between 68 and 90 is the medium social support; and values greater than or equal to 91 points correspond to high social support.

\section{Analysis of results and statistics}

Data were stored in a structured electronic spreadsheet in Microsoft Excel, with double typing, to ensure reliability in their compilation. Then, they were processed by the application Statistical Package for the Social Science (SPSS) for Windows, version 22.0, being analyzed through descriptive and inferential statistics.

The Kruskal-Wallis Test was used to associate functional capacity and social support dimensions, as the sample does not have a normal distribution, evaluated by the Kolmogorov-Smirnov Normality Test.

\section{RESULTS}

In this study, 108 individuals with sequelae of CVA participated, of which there was a greater prevalence of females $(57.4 \% ; n=62)$, aged between 66 and 80 years or older $(59.2 \% ; n=64)$, married or in a stable relationship (47.2\%; $n=51$ ), living with family $(86.1 \%$; $\mathrm{n}=93)$ and who have a caregiver $(76.6 \% ; \mathrm{n}=82)$, normally the offspring or spouse (39.1\%; $n=42$ e $34.1 \% ; n=36$, respectively).

Regarding the evaluation of functional capacity, there was a predominance of individuals with dependence (93.6 \%; $n=101)$, emphasis given to mild $(40.7 ; \mathrm{n}=44)$ or moderate dependence $(32.4 ; \mathrm{n}=35)$ (Table 1).
Table 2 shows the classification of the social support provided, and one can observe that $74.1 \%(n=80)$ of the patients exhibited low to medium social support, and $25.9 \%$ presented high social support.

Among the scale dimensions, material support was the most offered, and one can see the prejudice in positive social interaction (Table 3).

Table 1 - Barthel Index of individuals with sequelae of CVA, João Pessoa, Paraíba, Brazil, $2016(\mathrm{~N}=108)$

\begin{tabular}{lccc}
\hline \multicolumn{1}{c}{ Score } & Classification & $\mathbf{n}$ & $\%$ \\
\hline 0-4 points & Very seriously dependent & 07 & 6.5 \\
5-9 points & Seriously dependent & 15 & 13.9 \\
10-14 points & Moderately dependent & 35 & 32.4 \\
15-19 points & Slightly dependent & 44 & 40.7 \\
20 points & Independent & 07 & 6.5 \\
Total & & 108 & 100.0 \\
\hline
\end{tabular}

Table 2 - Social support in patients with sequelae of CVA, João Pessoa, Paraíba, Brazil, $2016(\mathrm{~N}=108)$

\begin{tabular}{ccc}
\hline Classification & $\mathbf{n}$ & $\%$ \\
\hline Low & 28 & 25.9 \\
Medium & 52 & 48.2 \\
High & 28 & 25.9 \\
Total & 108 & 100.0 \\
\hline
\end{tabular}

Table 3 - Dimensions of the social support scale, João Pessoa, Paraíba, 2016 $(\mathrm{N}=108)$

\begin{tabular}{lcccc}
\hline $\begin{array}{l}\text { Dimensions of } \\
\text { social support }\end{array}$ & Mean & $\begin{array}{c}\text { Standard } \\
\text { Deviation }\end{array}$ & $\begin{array}{c}\text { Amplitude } \\
\text { Minimum }\end{array}$ & Maximum \\
\hline Material & 18.94 & 1.99 & 4 & 20 \\
Afetiva & 12.19 & 3.32 & 3 & 15 \\
Emocional & 16.34 & 4.62 & 4 & 20 \\
Informação & 15.71 & 5.23 & 4 & 20 \\
Interação social positiva & 13.89 & 5.78 & 4 & 20 \\
\hline
\end{tabular}

Figure 1 shows the association of functional capacity and social support, in which one can see a statistically significant correlation between individuals with very serious dependence (VS) and high social support ( $p \leq 0.05)$.
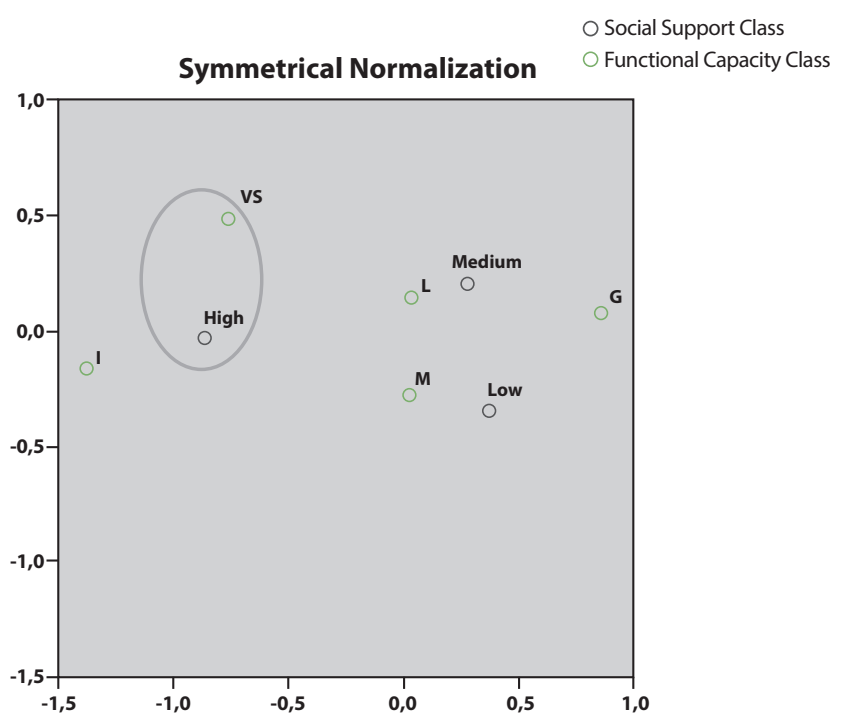

Figure 1 - Perceptual map of the correspondence analysis of the crossing between functional capacity and social support of individuals with sequela of CVA, João Pessoa, Paraíba, Brazil, 2016 
Table 4 - Association between functional capacity and dimensions of the social support scale, João Pessoa, Paraíba, 2016 ( $\mathrm{N}=108)$

\begin{tabular}{|c|c|c|c|c|c|c|}
\hline \multirow{3}{*}{$\begin{array}{l}\text { Dimensions of } \\
\text { social support }\end{array}$} & \multicolumn{5}{|c|}{ Functional capacity } & \multirow{3}{*}{$\begin{array}{c}P \\
\text { value }\end{array}$} \\
\hline & \multicolumn{4}{|c|}{ Dependent } & \multirow{2}{*}{ Independent } & \\
\hline & Very severe & Severe & Moderate & Mild & & \\
\hline Material & 19.86 & 19.27 & 19.06 & 18.77 & 17.86 & 0.674 \\
\hline Affective & 11.71 & 12.00 & 12.46 & 12.18 & 11.86 & 0.729 \\
\hline Emotional & 18.00 & 15.53 & 16.06 & 16.27 & 18.29 & 0.466 \\
\hline Information & 16.57 & 15.20 & 15.29 & 15.59 & 18.86 & 0.460 \\
\hline Interaction & 15.14 & 12.73 & 13.09 & 14.32 & 16.43 & 0.479 \\
\hline
\end{tabular}

The dimension of positive social interaction, which reflects the availability of people to perform leisure activities, was the least offered ${ }^{(13)}$. Studies indicate the social interaction has qualitative and quantitative aspects that influence the functionality and welfare of older adults $^{(27)}$. Thus, the reduced provision of it may lead to social isolation and increased depressive frameworks, affecting rehabilitation and reintegration into society

In this study, we observed a statistically significant correlation between seriously dependent individuals and high social support. Other research also showed similar results ${ }^{(24)}$. The provision of social support leads to increased self-care activities and preservation of subject

No statistically significant associations were not found between functional capacity and dimensions of social support ( $p \geq 0.5$ ), as shown in Table 4. However, one may notice that material and affective support was higher in dependent patients. On the other hand, the dimensions of emotional support, information and positive social interaction were the highest among independent patients.

\section{DISCUSSION}

This research was conducted with people presenting after effects of CVA. This sample is justified by the fact that patients with sequelae require greater social support for their rehabilitation and reintegration to society. Through data analysis, we observed that most patients were dependent for carrying out Activities of Daily Living (ADLs). Such finding can be explained by the physical impairment caused by this disease, which interferes with autonomy and independence ${ }^{(19)}$.

Functional capacity is extremely important for the realization of various roles in society and for the improvement of quality of life ${ }^{(20-21)}$. A research conducted with patients after the first CVA emphasizes the importance and proposes a model of care to the patient that goes from hospitalization to a plan of discharge; home care, referring to the assistance by the Family Health Strategy (FHS); informal care, involving the action of the family and other who take care of the patient; and self-care, which includes educational strategies so that dependence is minimized until independence is achieved ${ }^{(9)}$.

In this study, most patients presented low to medium social support, which is troubling since this is crippling disease, with a high need of family support and health care. The provision of support after CVA is fundamental in the individual's rehabilitation, quality of life and increased resilience, reducing sequelae and preventing mental illness that are commonly associated with this disease, such as depression ${ }^{(22-23)}$.

Regarding the dimensions of the social support instrument, we noticed that material support was the most offered. This refers to the availability of material resources and assistance in $\mathrm{ADLS}^{(13)}$. Other studies $^{(24-25)}$ also identified higher values in the material dimension of older adults with cognitive changes in the State of São Paulo and in individuals with multiple sclerosis in the city of Porto, Portugal.

However, despite being the dimension with the highest mean, in most cases the sequelae arising from CVA hamper the return to work activities and generate dependency for the ADLS of the person affected, often resulting in financial overload for the family, which assumes the general expenses of the patient, and this may compromise treatment and rehabilitation ${ }^{(26)}$. autonomy, taking into consideration their wishes and priorities. In a study performed with older adults, the association between increased functional capacity was clear when the support network was stronger ${ }^{(15)}$.

As for the association between the dimensions of social support and functional capacity, we found the dimensions positive social interaction and information had lowest means in dependent patients than in independent ones. This result is troubling, given that people with greater dependence present emotional instability, causing feelings of worthlessness and failure, which diminishes the interest in routine activities ${ }^{(27)}$.

Family has an important role in the emotional, social and economic aspects faced by people with physical and mental disabilities, contributing to a better quality of life. In a study with patients with schizophrenia, the social relationship was considered an important determinant of welfare ${ }^{(28)}$.

A study conducted with patients after CVA showed negligence and lack of guidance from support networks, especially nurses, in the transition from hospital to home care and in the whole rehabilitation, which led to dissatisfaction, fear, worries, and unpreparedness if the family in patient care ${ }^{(29)}$. In this regard, it should be noted that the involvement of health professionals in strengthening the entire social network, especially support to family members and caregivers, is of paramount importance ${ }^{(30)}$.

Among the strategies to increase social support, we can mention the early supply, increased intensity of contact between patient and family/friends/professionals, permanent evaluation and counseling $^{(23,31)}$. In addition, it is necessary that there is a transformation of society and the way it is organized, thus creating a feeling of solidarity and eliminating negative aspects of the capitalist system, such as individualism, which tends to keep people from each other ${ }^{(32)}$ and, consequently, to limit or eliminate the provision of support.

\section{Study limitations}

As the main limitation of this study, we emphasize the lack of a source of support in the instrument (friends, spouse, health institutions, co-workers, among others), as it is important to distinguish its origin because the proximity to a source of social support changes the behavior of the individual who receives it.

\section{Contributions to the field of Nursing}

Patients affected by CVA and their families should be included in the care planning of health professionals, with actions of 
active listening, support and dialogue. Thus, this research brings contributions to nursing care, highlighting the need for social support assessment, as well as of orientation during the hospital discharge of patients affected by CVA and their families, with emphasis on the peculiarities of the patient's health framework, what to expect after discharge and the types of social support that were identified as being more deficient.

This study may also subsidize the nursing practice in primary health care, expanding the assistance for the planning of psychoeducation and psychotherapy interventions to caregivers and family members of patients affected by CVA, which may contribute to improve the quality of life of everyone involved.

Findings of this study can be generalized to investigate the functional capacity ans social support of populations with other disorders, such as individuals with multiple sclerosis and older people with cognitive changes. This, conducting research in this conditions becomes essential, as well as in contexts such as cancer, trauma victims, deficiencies, among others, to broaden the knowledge on these conditions of disability.

\section{CONCLUSION}

Results exposed in this research show the prevalence of people with mild to moderate dependence and low to medium social support. No statistically significant associations were observed between functional capacity and dimensions of social support. However, there was a statistically significant association between very seriously dependent individuals and high social support.

We emphasize the importance of the participation of health professionals, including nurses, in strengthening the family as the main axis of support, as well as, in conjunction with public administrators and society, in using measures to strengthen the comprehensiveness of the Unified Health System, which is an indispensable principle fir the resolution of health issues.

\section{FUNDING}

This study was financed by the Coordination for the Improvement of Higher Education (CAPES) - Funding Code No. 001.

\section{REFERENCES}

1. Sajatovic M, Tatsuoka C, Welter E, Colon-Zimmermann K, Blixen C, Perzynski AT, et al. A targeted self-management approach for reducing stroke risk factors in African American men who have had a stroke or transient ischemic attack. Am J Health Promot [Internet]. 2018[cited 2018 Jun 19];32(2):282-93. Available from: https://www.ncbi.nlm.nih.gov/pubmed/28530142

2. Faria ACA, Martins MMFPS, Schoeller SD, Matos LO. Care path of person with stroke: from onset to rehabilitation. Rev Bras Enferm [Internet]. 2017[cited 2018 Jun 19];70(3):495-503. Available from: http://dx.doi.org/10.1590/0034-7167-2016-0579

3. Departamento de Informática do Sistema Único de Saúde do Brasil (DATASUS). Morbidade hospitalar do SUS [Internet]. 2017 [cited 2018 Jun 19]. Available from: http://www2.datasus.gov.br/DATASUS/index.php?area=0203\&id=6926\&VObj=http://tabnet.datasus.gov.br/cgi/ deftohtm.exe?sih/cnv/ni

4. Garritano CR, Luz PM, Pires MLE, Barbosa MTS, Batista KM. Analysis of the mortality trend due to cerebrovascular accident in Brazil in the XXI century. Arq Bras Cardiol [Internet]. 2012[cited 2018 Jun 19];98(6):519-27. Available from: http://www.scielo.br/pdf/abc/v98n6/ en_aop03812.pdf

5. Pereira RA, Santos EB, Fhon JRS, Marques S, Rodrigues RAP. Burden on caregivers of elderly victims of cerebrovascular accident. Rev EsC Enferm USP [Internet]. 2013[cited 2018 Jun 19];47(1):185-92. Available from: http://www.scielo.br/pdf/reeusp/v47n1/en_a23v47n1.pdf

6. Barbosa BR, Almeida JM, Barbosa MR, Rossi-Barbosa LAR. Avaliação da capacidade funcional dos idosos e fatores associados à incapacidade. Cienc Saude Coletiva [Internet]. 2014[cited 2018 Jun 19];19(8):3317-25. Available from: http://www.scielo.br/pdf/csc/v19n8/1413-8123csc-19-08-03317.pdf

7. Nunes DP, Nakatani AYK, Silveira EA, Bachion MM, Souza MR. Capacidade funcional, condições socioeconômicas e de saúde de idosos atendidos por equipes de Saúde da Família de Goiânia (GO, Brasil). Cien Saude Colet [Internet]. 2010[cited 2018 Jun 19];15(6):2887-98. Available from: http://www.scielo.br/pdf/csc/v15n6/a26v15n6.pdf

8. Costa TF, Gomes TM, Viana LRC, Martins KP, Costa KNFM. Stroke: patient characteristics and quality of life of caregivers. Rev Bras Enferm [Internet]. 2016[cited 2018 Jun 19];69(5):933-9. Available from: http://www.scielo.br/pdf/reben/v69n5/en_0034-7167-reben-69-05-0933.pdf

9. Rodrigues RAP, Marques S, Kusumota L, Santos EB, Fhon JRS, Fabrício-Wehbe SCC. Transition of care for the elderly after cerebrovascular accidents: from hospital to the home. Rev Latino-Am Enfermagem [Internet]. 2013[cited 2018 Jun 19];21(spe):216-24. Available from: http:// www.scielo.br/pdf/rlae/v21nspe/27.pdf

10. Holanda CMA, Andrade FLJP, Bezerra MA, Nascimento JPS, Neves RF, Alves SB, et al. Support networks and people with physical disabilities: social inclusion and access to health services. Cienc Saude Coletiva [Internet]. 2015[cited 2018 Jun 19];20(1):175-84. Available from: http:// www.scielo.br/pdf/csc/v20n1/1413-8123-csc-20-01-00175.pdf

11. Due P, Holstein B, Lund R, Modvig J, Avlund K. Social relations: network, support and relational strain. Soc Sci Med [Internet]. 1999[cited 2018 Jun 19];48(5):661-73. Available from: https://www.ncbi.nlm.nih.gov/pubmed/10080366

12. Boas LCGV, Foss MC, Freitas MCF, Pace AE. Relationship among social support, treatment adherence and metabolic control of diabetes mellitus patients. Rev Latino-Am Enfermagem [Internet]. 2012[cited 2018 Jun 19];20(1):52-8. Available from: http://www.scielo.br/pdf/rlae/ v20n1/08.pdf 
13. Southwick SM, Sippel L, Krystal J, Charney D, Mayes L, Pietrzak RH. Why are some individuals more resilient than others: the role of social support. World Psychiatry [Internet]. 2016[cited 2018 Jun 19];15(1):77-9. Available from: https://www.ncbi.nlm.nih.gov/pmc/articles/ PMC4780285/

14. Yokokawa Y, Miyoshi K, Kai I. Activities of daily living (ADL) of single elderly individuals using social assistive programs in a rural community. Nihon Koshu Eisei Zasshi [Internet]. 2017[cited 2018 Jun 19];64(6):330-6. Available from: https://www.ncbi.nlm.nih.gov/pubmed/28890531

15. Dutra FCMS, Silva HRO. Bem estar subjetivo, funcionalidade e apoio social em idosos da comunidade. Estud Interdiscipl Envelhec [Internet]. 2014[cited 2018 May 12];19(3):775-91. Available from: http://seer.ufrgs.br/index.php/RevEnvelhecer/article/view/43389/33285

16. Minosso JSM, Amendola F, Alvarenga MRM, Oliveira MAC. Validation of the Barthel Index in elderly patients attended in outpatient clinics, in Brazil. Acta Paul Enferm [Internet]. 2010[cited 2018 May 12];23(2):218-23. Available from: http://www.scielo.br/pdf/ape/v23n2/en_11.pdf

17. Griep RH, Chor D, Faerstein E, Werneck GL, Lopes CS. Validade de constructo de escala de apoio social do Medical Outcomes Study adaptada para o português no Estudo Pró-Saúde. Cad Saude Publica [Internet]. 2005[cited 2018 May 12];21(3):703-14. Available from: http://www. scielo.br/pdf/csp/v21n3/04.pdf

18. Gonçalves TR, Pawlowski J, Bandeira DR, Piccinini CA. Avaliação de apoio social em estudos brasileiros: aspectos conceituais e instrumentos. Cienc Saude Coletiva [Internet]. 2011 [cited 2018 May 12];16(3):1755-69. Available from: http://www.scielo.br/pdf/csc/v16n3/12.pdf

19. Ministério da Saúde (BR). Secretaria de Atenção à Saúde. Departamento de Ações Programáticas Estratégicas. Diretrizes de atenção à reabilitação da pessoa com acidente vascular cerebral [Internet]. Brasília, DF: Ministério da Saúde; 2013[cited 2017 Oct 11]. 72p. Available from: http://bvsms.saude.gov.br/bvs/publicacoes/diretrizes_atencao_reabilitacao_acidente_vascular_cerebral.pdf

20. Cruz DMC, Emmel MLG. Associations among occupational roles, independence, assistive technology, and purchasing power of individuals with physical disabilities. Rev Latino-Am Enfermagem [Internet]. 2013[cited 2017 Oct 11];21(2):1-8. Available from: http://www.scielo.br/ pdf/rlae/v21n2/0104-1169-rlae-21-02-0484.pdf

21. Rangel ESS, Belasco AGS, Diccini S. Quality of life of patients with stroke rehabilitation. Acta Paul Enferm [Internet]. 2013 [cited 2017 Oct 11];26(2):205-12. Available from: http://www.scielo.br/pdf/ape/v26n2/en_v26n2a16.pdf

22. Villain M, Sibon I, Renou P, Poli M, Swendsen J. Very early social support following mild stroke is associated with emotional and behavioral outcomes three months later. Clin Rehabil [Internet]. 2017[cited 2017 Oct 11];31(1):135-41. Available from: https://www.ncbi.nlm.nih.gov/ pubmed/26851250

23. Padberg I, Knispel P, Zöllner S, Sieveking M, Schneider A, Steinbrink J, et al. Social work after stroke: identifying demand for support by recording stroke patients' and carers' needs in different phases after stroke. BMC Neurol [Internet]. 2016[cited 2017 Oct 11];16:111. Available from: https://www.ncbi.nlm.nih.gov/pmc/articles/PMC4955160/

24. Brito TRP, Pavarin SCI. The relationship between social support and functional capacity in elderly persons with cognitive alterations. Rev Latino-Am Enfermagem [Internet]. 2012[cited 2017 Oct 11];20(4):677-84. Available from: http://www.scielo.br/pdf/rlae/v20n4/07.pdf

25. Costa DC, Sá MJ, Calheiros JM. The effect of social support on the quality of life of patients with multiple sclerosis. Arq Neuropsiquiatr [Internet]. 2012[cited 2017 Oct 11];70(2):108-13. Available from: https://www.ncbi.nlm.nih.gov/pubmed/22311214

26. Simeone S, Savini S, Cohen MZ, Alvaro R, Vellone E. The experience of stroke survivors three months after being discharged home: a phenomenological investigation. Eur J Cardiovasc Nurs [Internet]. 2015[cited 2017 Oct 11];14(2):162-9. Available from: https://www.ncbi. nlm.nih.gov/pubmed/24491347

27. Chen L, Xiao LD, De Bellis A. First-time stroke survivors and caregivers' perceptions of being engaged in rehabilitation. J Adv Nurs [Internet]. 2016[cited 2017 Oct 11];72(1):73-84. Available from: https://www.ncbi.nlm.nih.gov/pubmed/26399942

28. Munikanan T, Midin M, Daud TIM, Rahim RA, Bakar AKA, Jaafar NRN, et al. Association of social support and quality of life among people with schizophrenia receiving community psychiatric service: a crosssectional study. Compr Psychiatry [Internet]. 2017[cited 2017 Oct 11];75:94-102. Available from: https://www.ncbi.nlm.nih.gov/pubmed/28342379

29. Silva JK, Vila VSC, Ribeiro MFM, Vandenberghe L. Survivors' perspective of life after stroke. Rev Eletr Enf [Internet]. 2016[cited 2017 Oct 11];18:e1148. Available from: https://revistas.ufg.br/fen/article/download/34620/21190+\&cd=1\&hl=pt-BR\&ct=clnk\&gl=br

30. Vincent-Onabajo GO, Muhammad MM, Ali MU, Masta MA, Aliyu HN. Social support after stroke: influence of source of support on stroke survivors' health-related quality of life. INDJ [Internet]. 2016[cited 2018 May 12];5(1):1-9. Available from: http://www.journalrepository.org/ media/journals/INDJ_29/2015/Sep/Onabajo512015INDJ20240.pdf

31. Meurer WJ, Barth BE, Gaddis G, Vilke GM, Lam SH. Rapid systemic review: intra-arterial thrombectomy ("Clot Retrieval") for selected patients with acute ischemic stroke. J Emerg Med [Internet]. 2017[cited 2018 May 12];52(2):255-61. Available from: https://www.ncbi.nlm.nih.gov/ pubmed/27863833

32. Juliano MCC, Yunes MAM. Reflections on the social support network as a mechanism for the protection and promotion of resilience. Ambient Sociedade [Internet]. 2014[cited 2018 May 12];17(3):135-52. Available from: http://www.scielo.br/pdf/asoc/v17n3/en_v17n3a09.pdf 